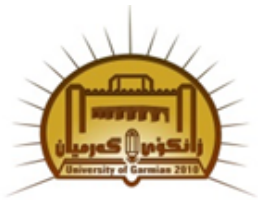

Available online at http://jgu.garmian.edu.krd

Journal of University of Garmian

https://doi.org/10.24271/ garmian.196234

\title{
An Assessment of EFL Students' Performance in the Area of Linguistics Humorous Texts
}

\author{
Ban Shihab Ahmed \\ College of Language and Human Sciences, University of Gramian
}

\section{Article Info}

Received: April, 2019

Revised:April,2019

Accepted:April,2019

\section{Keywords}

Intestinal parasites, Ectoparasites, Rattus rattus, Garmian region, Iraq

\section{Corresponding Author}

ban.shahab@garmian.edu.krd

\begin{abstract}
Humor brings people together under shared laughter. However, since humor requires highly sensitive linguistic and cultural competence, expressing and appreciating humor is often a challenge in cross-cultural communication. What is considered as funny may differ across cultures. This paper discusses the ability of the EFL to distinguish humorous and unhumorous texts, and more specifically investigates the types of humor in the language classroom. At the outset of the paper, some theoretical backgrounds have been provided to account the use of humor and its styles, types and theories. To achieve the aims of the study the collected data of the test which has been applied on a sample of EFl university students, the data have been analyzed by using SPSS . The results have shown that the subjects faces difficulty in the recognition of humouros text generally and its types particularly. since lexical ambiguity is the core of language - based jokes, this paper examines and reviews this ambiguity and the humorous effect presented by humor. Students' errors can be attributed to certain factors among which the lack of using English humor in real life situation in communicative ways and the deficiency of focusing on sense of humor in literature subjects curricula during their university study .
\end{abstract}

\subsection{Introduction}

Humor is a universal and fundamentally social phenomenon. People use it as a form of expression in all kinds of interaction. Humour has always been one of the major challenges for EFL learners especially when it comes to expressing extra linguistic elements such as culture. Even though humour is said to be universal, each culture has its own, and sometimes one culture's humour is hard to understand for others . Humor is seen as multidimensional and Humor is seen as multidimensional and includes the abilities to produce, recognize, and appreciate humor and to use humor as a coping strategy. Humor, in theory, is complex to attain. Despite the number of thinkers who have participated in the debate, the topic of humor is currently understudied in the discipline of philosophy.
There are only a few philosophers currently focused on humor-related research, which is most likely due to two factors: the problems in the field have proved incredibly intricate, inviting repeated failures, and the subject is erroneously dismissed as an insignificant concern. Culture plays an important role in the realm of comedy and humor. Audiences from different cultural backgrounds respond unevenly when presented the same scene from a movie; let alone audiences who do not speak the same language. It is important to keep in mind that humor serves the purpose of entertaining, and being completely faithful to source text at the moment of translating does not seem to be a suitable procedure; the text involved in 
the translation process needs to be treated according to the audiences it is targeted to.

Once explained the challenge of proposing a definition of humor it is easier to comprehend the importance of analyzing humor.

\subsection{The Problem}

The problem of this research is the lack of information and studies about the humor, and specially the students' ability to master the recognition of humor and its type in literary studies. There are several theories that explain how humor is performed and how it works in different situations, but there is little information about how to recognize humorous situations. There is a real need to find out whether there is a difficulty in dealing with humor and recognizing its types and forms as well at college level.

\subsection{The Aims of the Study}

1-The study aims to find whether or not EFL university students face difficulties in recognizing humor .

2- Identifying the difficulty in recognizing the types of humor and the most problematic type and the most easiest one.

3-Finding out whether there are any significant differences between student means scores in recognizing humor on one hand and its types on the other hand .

4-Finding the differences in students 'performance according to the selected types of humor .

\subsection{The Hypotheses}

In order to achieve the aims of the study the following hypotheses are put forward:

EFL university students face difficulties in general in recognizing humor .

EFL learners also face difficulty in recognizing the types of humor.

There is a significant differences in students performance in recognizing humor and its types.

\subsection{The Procedure}

In order to investigate the hypotheses of this study and achieve the aims the following steps will be followed:

1-Selecting number of Iraqi EFL university students to represent the sample of the study .

2-Constructing an achievement test suitable to the purpose of the study and ensuring its validity and reliability.

3-Adminstering the test to the selected sample .

4-Collecting the data and analyzing them by using SPSS to aotain the required results.

5- Drawing conclusion based on the findings of the study.

\subsection{The value}

This study is useful and constructive for those who deal with studying humor in the teaching English as a second language. It is also for valuable those who are interesting in applied linguistics and the pedagogical importance of students' errors in the area under study.

\subsection{On defining of humor}

As humor has a relation with different disciplines : psychology, sociology and linguistics, so that there is no consensus on the definition of humor and its categories.

In linguistics, humor and pragmatics are considered as interdisciplinary. Thus, humor is defined by Martin (2007) as " involving the communication of multiple, incongruous meanings".

According to The New Oxford Dictionary of English, the very original meaning of "humor" is "one of four liquids (blood, phlegm, choler, melancholy) in our body, said to determine a person's mental and physical qualities." When this word was introduced into art, it was something negative that referred to odd, funny and affected temperament. Finally, in the late 17 th century, a new definition of humor appeared in The New Oxford Dictionary of English and it is at the basis of the modern meaning of humor.

(The Free Dictionary),simply defines the term humor as "the quality that makes something laughable or amusing; funniness". Bariaud deals with the topic of humor as "specific experience engendered by the perception of a 'funny' or 'amusing' event. Another perspective is presented by Merriam-Webster6 dictionary; among many stated definitions, it also says that "[humor] is the mental faculty of discovering, expressing, or appreciating the ludicrous or absurdly incongruous" and "something that is or is designed to be comical or amusing".

Humor is "the quality in something that makes it funny or amusing; the ability to laugh at things that are amusing."

(Oxford Advanced Learner's English-Chinese Dictionary, Sixth edition, P 863)

Humor is "the quality in something that makes it funny: "amusement" or "the ability to understand and enjoy funny situations or to laugh at things."

(Longman Dictionary of Contemporary English, P 698).

Šed'ová adds to this definition that the term can be related to both perception (i.e. humorous reaction) and creation (i.e. humorous action) of something amusing. Moreover, humor can be referred exclusively to a sympathetic, tolerant and benevolent form of amusement but not wit (Wickberg 1998). Both cognitive and emotional elements are included in humor, thus, humor could be a state or a trait (Martin 2000) . 
Another definition by $\operatorname{Martin}(2007$ : 5) who considers humor as a broad term that refers to anything that people say or do that is perceived as funny and tends to make others laugh, as well as the mental processes that go into both creating and perceiving such an amusing stimulus, and also the affective response involved in the enjoyment of it.

Humor is "highly personal, subjective, and contextual and we cannot always predict the way it will be received, things that one person finds humorous, ironic, or funny may be viewed by others as trite."(Garner, 2006 p. 178).

Munoz (2005, p.24) argues that 'humor is closely related to memory as it is easier to recall an experience that occurred in a humorous context...'

Decker(1987, as quoted in Holmes, 2000: 160) argues that "humor is an essential tool for managers" as it helps workplace leaders to accomplish transactional goals while facilitating relational tasks effectively.

Obviously, the above definitions are general. The working definition for the present study, refers to all things that are laughable, amusing, funny which can be called as " humor", with focusing of the aspect of comprehension. And that is the basis of this study.

\subsection{Theoretical Background of Humor.}

All the theories which have been advanced by famous philosophers such as Plato, Aristotle, Hobbes, Schopenhauer, and Kant dealt with the question of why people laugh at certain situations, whereas they do not show any reactions in others. They tried to explain the various mental processes that allow us to experience humor. Plato and Aristotle began to deal with the essence of humor about 2000 years ago and laid the foundations for today's modern theories of. Attardo(1994) compresses them to the three major groups: superiority theory, relief theory and incongruity theory. Morreall (1987) claims that "a good way to get the insight necessary for constructing a comprehensive theory of laughter is to examine the three traditional theories; though none of them is adequate as a general theory, they each have features which belong in a general theory" (p. 129). Following this approach, we have chosen to present the three theories that he proposes: the superiority theory, the relief theory, and the incongruity theory. They are also the foundation for modern humor analys is

\subsection{Superiority Theory}

Xiaosu(2009:8) presents that this theory is the basis for modern social theory about humor in which aggression, disparagement and superior feeling play an important role. The assumption of the superiority theory is that we laugh at the misfortunes of others; it reflects our own superiority. This theory can be found in the works of Plato, Aristotle, and Hobbes (Barnes, 1992: 87-95). Plato suggests that humor is some kind of malice towards people who are being considered relatively powerless. Hobbes (ibid) further explains that humans are in constant competition with each other, looking for the shortcomings of others. He considers laughter as an expression of a sudden realization that we are better than other persons, an expression of "sudden glory". This theory is also called laugh/win theory, according to (Gruner 2000: 9)as cited in Xiaosu(2009:8) this theory includes:

1. For every humorous situation, there is a winner.

2. For every humorous situation, there is a loser.

3. Finding the"winner" in every humorous situation, and what that "winner" wins, is often not easy.

4. Finding the "loser" in every humorous situation, and what that "loser" loses, is often even less easy. But, that having been said.

5. Humorous situations can best be understood by who wins what, and who loses what.

6. Removal from a humorous situation (joke, etc.) what is won or lost, or the suddenness with which it is won or lost, removes the essential elements of the situation and renders it humorless.

\subsection{Relief theory}

According to Freud (1856-1938), relief or release theory implies "Humour released by 'excess' nervous energy which actually masks other motives and/or desires" (cf. McCreaddie \& Wiggins, 2008, p. 585). The relief theory has a clear physiological or psychophysiological nature (Rutter,1997). The theory reached its zenith when Freud proposed his theory that laughter can release tension and "psychic energy". Freudís psychoanalytical assertions is that humor operates as a socially acceptable way to alleviate sexual and aggressive tension (Matte, 2001). Freud was largely influenced by the work of Spencer who suggested laughter worked as something of a release valve for nervous energy in the body, similar to Darwinís (1890/1965) observations of primate facial expressions thought to relieve tension (Lynch, 2002).

Laughter and humor are considered to be more socially appropriate release channels than aggressive behaviors. Relief theories, in short, provide an 8 umbrella for studies examining the pleasurable effects that arise out of humor creation and appreciation as a result of relieving personal stress or social tension. In an applied setting, the concept underlying relief theory can be viewed in a study of grade school children by McGhee (1979). McGhee found a strong relationship between sense of humor (measured through a combined score of frequency of laughter and communicative attempts, both verbal and nonverbal, of humor during spontaneous play) and behavioral forms of verbal and physical aggressiveness and dominance. A more conventional version of the relief theory is that we experience a pleasant sensation when humor replaces negative feelings like pain or sadness (Mulder 
\& Nijholt, 2002: 4). The theory does not really give an explanation of why we find things funny, and in fact it can be seen as a theory of laughter.

\subsection{The incongruity theory}

The incongruity theory offers a radically different explanation of what humor

results from. Traced back to Aristotle, incongruity is the most widely accepted philosophical theory of humor to date (Morreall, 1989)_-"amusement is the enjoyment of something which clashes with our mental patterns and expectations" (p. 1). People understand humorous communication if they are (cognitively) able to resolve the incongruity (Banas et al., 2011). This theory can be traced to Francis Hutcheson's 1750 "Reflections upon Laughter, and Remarks upon the Fable of the Bees" (Critchley, 2002, p. 3) but it is Immanuel Kant and later Arthur Schopenhauer who made major contributions to its development. incongruity theory emphasizes cognition, requiring the mental capacity to note, understand, and categorize incongruous changes and thus to comprehend a situation and its implications before humor (the cognitive state of mirth) can be experienced. Thus, humor comprehension, but not humor appreciation, is at the core of incongruity theories. According to this theory, humor resides in an intellectual recognition of incongruity between what we know or expect to occur, and what The Use of Humor in the Multicultural Working Environment 21 actually occurs in the joke, gag, or blague (Critchley, 2002, p. 3). The idea of incongruity is crucial to Kant's account of laughter, which he defines as an "affection arising from the sudden transformation of a strained expectation into nothing" (Morreall, 1983, p. 16). In other words, when the punchline comes, the tension is gone and the listeners experience comic relief. Schopenhauer's views are somewhat different. We do get something in the punchline: something that we were not expecting, something that completes the story but in an unexpected way. Amusement derives from a mismatch between a thought and a perception. He defines it in the following way: "the cause of laughter in every case is simply the sudden perception of incongruity between a concept and the real objects which have been thought through it in some relation, and laughter itself is just the expression of this incongruity" (as cited in Morreall, 1983, p. 17).

\subsection{Morreall's Theory}

Morreall(1983)explains that the above mentioned theories fail to account for all instances of humour. $\mathrm{He}$ puts forward a new theory in which he tried to incorporate all three previous theories. the formula of this theory is that "Laughter Results from a Pleasant Psychological Shift" (Morreall, 1983, p.39). This theory identifies three general features of laughter situations: the person who laughs undergoes a change of psychological state: this change is sudden, and it is pleasant. The psychological shift may be cognitive (as in the cases of incongruities), affective (as in the cases explained by the superiority and relief theories), or both (as in the cases of hostile humour). In so reasoning, Morreall tries to take all humour instances that could be explained by each single previous theory into account. The second feature, the suddenness in a psychological change, is explained by Morreall (1983) as related to the amount of change and the time over which the change takes place. For a change to be sudden, the amount is relatively large and the time is relatively short; as well, the person at the receptive end of the change does not know about the change in advance. This feature, according to Morreall, explains why we cannot tickle ourselves to laugh, why the "punch line" of jokes has such a name, why explaining a piece of humour to someone will hardly make them laugh, and why most pieces of humour will appear most funny to us the first time we come across them. The last feature of laughter situations, as suggested by Morreall (1983), is the pleasure in laughter. Morreall mentions the example of finding out that one has won a lottery Chapter 2: Literature review 23 as a pleasant psychological shift, while discovering that a friend has been killed is not. A psychological shift can be unpleasant if it evokes such negative emotions as fear, pity, anger, disgust, or an attitude of puzzlement, wonder, or problem solving. Morreall went on to indicate that for a psychological shift to be perceived as pleasant, we should feel relatively secure at the time. This element of security implies that even though we experience a psychological shift, we still feel in control of the situation, e.g. watching someone fall out of an airplane in a slapstick movie, because we know that it is not real. Morreall (1983, p.54) argues that we 'often try to get children, and adults too, to regain their feeling of security [...] by making them laugh' and, therefore, there is a two-way causal relation between our feelings and the behaviour expressing those feelings. In this case, 'laughing is a behaviour that expresses pleasant feelings. But this behaviour is itself pleasant, and so tends to increase pleasant feelings' (p.55). Morreall's argument of laughter and security may be of great value for educational settings where the presence of laughter could mean the introduction of not only pleasure, but also a sense of security to learners. Both pleasure and security, as we shall see in the discussion of humour in education (see 2.5), are among the factors facilitating successful learning. Also, the pleasant psychological shift that humour brings about can be an effective antidote for learning anxiety, especially language learning anxiety.

\subsection{Functions of humor}

Humor can be used for serious functions, of social behavior among which: 


\section{1-Social function}

According to Raskin(2008) as cited in Majeed (2014:24) humor is a social phenomenon, humorous utterances are considered as a form of communication that is usually shared in social interaction .They are socially and culturally shaped in specific time and place, jokes are generally central to social ,cultural and moral order of a society .

Palmer (1994:58) asserts the idea that humor is a form of social control of evidence . he constructs a hierarchy of acts of increasing deviance and a hierarchy of sanctions against them .minimal deviances say, a mildly eccentric behavior will attract no sanction at all or only the mildest and most informal of sanctions.

Martin (2007:14) explains that humor is best viewed as a form of play that comprises cognitive ,emotional and expressive components . all of these elements humor have a social dimension which serves important social functions that likely contributed to the evolutionary survival.

Humor may function as a form of social control in the sense that it enables people to address threatening or taboo topics and sharing information on these unmentionable subjects requires interlocutors to negotiate rule suspension in order to tell a particular joke.(Doktorwurde(2003:15) as cited in Majeed (2014:25).

\subsection{Psychological Function}

According to Doktorwurde(2003:13) humor has beneficial effect on health and well-being .It reduces stressful experiences that would result in dysphonic emotions.

Martian(2007:15) states that the psychological function includes a cognitive and social benefits of the positive emotion of mirth and the use of humor as a way of relieving tension which have changed over centuries from being essentially aggressive and socially inappropriate to being seen as positive ,psychologically, physically, socially and healthy desirable.

Hey (2000:725)considers defending humor show the psychological function which mean protecting the self by identifying the weakness before anyone else does and to reveal personal information about oneself .

He asserts that using humor as a coping mechanis $m$ in stressful situations are more likely to foucus on the problem and exhibit minimal emotional responses and to remain in contact with reality and express emotional involvement.(Ibid:14)

According to Banas( et al., 2011)There are several reviews about the general functions of humor .Assumptions about how the general or specific functions of humor are related to humor theories are limited. For instance, interpersonal functions such as enhancing one's own liking and status might refer to superiority theories.whereas stress reduction via humor and laughter may be explained by arousal-relief theories The proposed functions of humor are often inductively derived theoretical assumptions or generalizations of empirical investigations of details. Thus, empirical research on nearly every function is recommended. That said, we will now summarize the proposed intrapersonal and interpersonal functions of humor and humor at work.

\subsection{Intrapersonal Functions}

Humor may serve to enhance relationships with others( Martin et al., 2003). Humor may also help individuals cope with stress: Humor can help people see the amusing side of problems and can help them distance themselves from stressors (Banas et al., 2011). Humor is said to enable a change in perspective and to buffer the effects of stress by serving as a coping strategy. In the same way, humor helps to regulate emotions. The intrapersonal function of disparagement humor, according to Freud (1905, 1960), is the venting of aggressive feelings in a socially acceptable way. Based on his experiences in Nazi concentration camps, Obrdlik (1942) saw the main function of gallows humor as morale strengthening - enhancing for the ingroup, disparaging for the outgroup. As this example demonstrates, the boundaries between intra- and interpersonal functions of humor are blurry. Though these functions apply to humor in general, they naturally apply to work settings, too. However, the relevance and consequences might differ between nonwork and work contexts.

\subsection{Interpersonal Functions}

The social functions of humor as abrasive or lubricating laughter, as a result of humor, may create both closeness and distance between individuals .Beyond providing amusement, humor can facilitate liking and can bring people together, but it may be also used to disparage others and socially isolate them (Banas et al., 2011). Thus, several authors have indicated that humor can increase/decrease closeness and power and can, therefore, influence the two main dimensions in person perception: liking and status. Among the positive functions is an increase in group cohesion, but it might also serve negative functions such as derision and social isolation. In the same line of thinking, Alexander (1986) distinguished between affiliative humor with its focus on creating or maintaining group cohesiveness, and ostracizing humor, which singles out a victim. Whereas most functions of aggressive humor elicit negative consequences, some may be potentially positive. Meyer (2000) states that Humor serves four basic functions in communication: Two tend to unite communicators (mutual identification, clarification of positions and values), and two tend to divide communicators from each other (enforcement of norms, differentiation of acceptable vs. unacceptable behaviors or people). These functions of humor in 
communication as, alternately, unifier or divider, allow humor to be used to delineate social boundaries.

\subsection{Styles of Humor}

According to Mulkay (1988) as cited in U. Michalik and I. Sznicer ( 2017:22-23) human interaction appears to fall into two basic modes, serious, and humorous, irrespective of cultural context. Humorous communication may employ various styles of humor. (Romero \& Cruthirds(2006:59) state that researchers propose that there are four such styles which can be employed in the working environment, each either positive or negative as follows :

\subsection{Affiliative humor}

It is called "a social lubricant" which is an example of positive humor. It is perceived to be neither threatening nor hostile which is contributed to the positive atmosphere in the workplace as it enhances social interaction and acts as a bond which brings people together. Those who use this type of humor joke around, tell funny stories, and play harmless practical jokes on their colleagues to facilitate communication within a particular group, lessen tensions and help build interpersonal relations, thereby improving the overall atmosphere and creating a positive working environment.

\subsection{Self-enhancing Humor}

is centered more on the individual. People who exhibit self-enhancing humor It

usually have a good-natured attitude towards life and are not easily overwhelmed with problems. They use humor as a coping mechanism for dealing with stressful situations as it helps them maintain a positive perspective and look at problems from a different, more humorous angle.

10.3 Aggressive humor

It is an example of negative humor directed at others. It is used to manipulate people by means of indirect threat or ridicule. As Romero and Cruthirds (2006) observe, it is used to "victimize, belittle and cause others some type of disparagement" (p. 59). Aggressive humor often leads to alienating people and undermining relationships and so does not bring positive effects for the organization. However, mild aggressive humor is believed to have positive functions.

\subsection{Types of humor}

Humour is the focus of scholarly studies conducted from philosophical, psychological, sociological, anthropological and linguistic perspectives. linguists analysing its semantic, cognitive, sociolinguistic or pragmatic mechanisms narrow down the scope of their investigation to its particular manifestations, which are many. Verbal humour which is of interest to linguists which is understood as that produced by means of language or text (cf. Raskin 1985; Attardo and Raskin 1991; Chiaro 1992; Attardo 1994).

Many different types of verbal humor are introduced which create humor in its own way as cited in Majeed (2016:31) . They are as follows :

\subsection{Jokes}

According to Martin(2007:11-17) jokes are short, amusing stories ending in a punch line. These are sometimes also referred to as "canned jokes" to distinguish them from the sorts of journal jesting and witty quips to which the words joke and joking can also refer. Jokes in every day conversations can be distinguished as verbal and non-verbal. The (canned) 2 joke is commonly considered the prototypical form of verbal humor, produced orally in conversations 3 or published in collections. Even if the concept is by no means unfamiliar to lay language users, who intuitively grasp its meaning, it does pose definitional problems. Most frequently, this humor category is defined in terms of its parts. Jokes in their various forms represent a genre which we regularly encounter in everyday life. It is important to realize that not all jokes are necessarily narrative. There are also jokes which are not narrative in their form, such as one-liners and riddle jokes. The structure of the joke includes a setup and a punch line, the last sentence of the setup creates a particular set of expectation about the situation interpretation. The punch line suddenly shifts the meaning in a playful way, so that creating the non-serious incongruity is necessary for humor to occur.

Ex.1 A mother mouse and a baby mouse were walking along, when all of a sudden, a cat attacked them. The mother mouse yelled, "BARK!" and the cat ran away.

"See?" said the mother mouse to her baby. "Now do you understand why it's important to learn a foreign language?"

Attardo (1994:95-96) explains two types of jokes :verbal and referential jokes. The former based on the meaning of the elements of the text makes reference to the phonological realization of the text .while referential jokes based exclusively on the meaning of the text without reference to the phonological realization of the lexical items of other units in the text.

\subsection{Word play (punning)}

Pun is also considered one of the ways to create humor. It was defined by the Shorter

Oxford Dictionary as "the use of the word in such a way as to suggest two or more meanings, or the use of two or more words of the same sound with different meanings so as to produce a humorous effect; a play on words" (As cited in Delabastita, p. 57).

Ex.2 Heard about the fight down town? It was called a shopping maul 
An old teacher never dies. They simply lose their class..

Without geometry, life is pointless

\subsection{Sarcasm}

Herawan, Deris and Abauagy (2014:281) define sarcasm as "the use of irony to mock or convey contempt" and "it is the activity of saying or writing the opposite of what you mean, or of speaking in a way intended to make someone else feel stupid".

Ex.3 Mary is a thoroughly delightful woman with a delightful figure, a delightful dress sense, a delightful brain and an equally delightful husband to match. So much delight is entirely overwhelming and I must decline her invitation to dinner.

\subsection{Irony}

Irony is considered the most common way to create humor. Quintilian said that "irony, Irony is using words to imply the opposite of their literal meaning, or a situation where the outcome is the opposite from that intended or expected. is that figure of speech or trope in which something, which is contrary to what is said, is to be understood" (As cited in Gordon, 1999, p. 118). Irony and sarcasm are often regarded as being synonymous

Ex.4'What pleasant weather!' - said while walking through a hails torm.

\subsection{Anecdotes}

Another humorous form is the anecdote. This is a humorous narrative by means of which the speaker regales the hearer with a story deriving from hisher personal experience or other people's lives (Norrick 1993, 1994, 2003). Frequently, the speaker presents an event from someone else's life as if it were autobiographical. Apart from narratives presenting (ostensibly) personal episodes, prevalent are those about the famous, which are published in collections and passed on orally. Anecdotes are delivered in a colourful style abounding in witty lexemes and phrasemes, coupled with rich non-verbal expression (the tone of voice, facial expression and gestures), which contribute to the humorous effect. It is not uncommon for such stories to refer to events which were hardly humorous and even dramatic, but are, however, recounted jovially to elicit a humorous response in the addressee.(As cited in Marta,2009:1295).

Ex.5 My flight back home was full of surprises. At the airport in Paris, customs officers wouldn't let me keep the wine I had bought at the Portuguese airport. It goes to your head ... and knees very easily. For over 20 minutes we conducted a rhetorically rich dialogue You can't carry any liquid onto the plane'. 'I think I can. I was informed I would be allowed to'. 'No, you can't'. I was just about to empty the two bottles, but I asked for the reasons. What I heard was, 'You can only have liquids bought at European airports in your hand baggage'. The French are so lovely and knowledgeable, aren't they? I felt like a primaryschool teacher, explaining to them the difference between Lis bon and Lebanon.

\subsection{Self-Denigrating Humor}

The most peculiar pragmatic type of humour comes into being when the speaker directs a brickbat at himherself, which is known in literature as selfdisparaging, self-denigrating or self-deprecating humour, as well as self-mockery or self-directed joking

This form of humour is an indication of preconceived self-presentation politics and selfassuredness underlying a self-deprecating act. It is more self-teasing than a self-putdown, inasmuch as the speaker does not genuinely aim to disparage him herself.. Self-deprecation produced in an awkward situation is a manifestation of the speaker's intelligence and composure, as he /she seems not to have lost his/ her bearings. Therefore, applying the technique of self-deprecation, the speaker displays his/her positive self-image and, in particular, one of the virtues in contemporary societies, i.e. the ability to laugh at one's inabilities or problems (cf. Norrick 1993)

Ex.6. My brain must be on the standby mode.

Ex.7 . In today's performance, the role of the idiot will be played by myself.

\subsection{Satire}

Quinn (2006:374) claims that satire is a type of humor that aims to ridicule folly in a society, an institution, or an individual. It uses laughter as a weapon against any target that the satirist considers silly, stupid, or vicious. Thus it is a negotiation between the judgmental and the joyous .

According to ( https://www.write-out-loud.com/typesof-verbal-humor.html ) Satire is used to expose silliness, foolishness or stupidity through ridicule. It attacks with the aim of alerting its audience to problems and to make way for reform. The form has its roots in antiquity and is seen today in many forms.

\subsection{Teasing}

Martin( 2007)states that teasing can be conceptualised as a higher-order concept embracing jocular utterances performing a variety of pragmatic functions (such as mock challenges, threats or imitation) the meaning of which is not to be treated as truth-oriented and which invariably carries humorous force to be appreciated by both interlocutors. teasing is considered to be inherently playful but it may be argued that the degree of aggression in teasing is gradable and can even be non-existent. In addition, such aggression, if present, is only ostensible. So that, for producing a tease, the speaker does not mean to be genuinely offensive towards the hearer, challenging the latter jocularly, i.e. speaking within a humorous frame, even if simultaneously implicitly conveying pertinent 
meanings outside it. Supposing the speaker intends to be hurtful, a putdown .

Ex.8 Female: You manifest the Peter Pan syndrome. Male: And you have the Captain Hook syndrome. (teasing)

Female: There's no such syndrome.

Male: Obviously there is. You have it!

\subsection{Witticism}

Wit is described as a style of humor. a "spontaneous creativity", and the witty person has "the talent or quality of using unexpected associations between contrasting or disparate words or ideas to make a clever humorous effect" (Arbuckle, 2008, p. 13). It is also referred to as a wisecrack, a quip8 or an epigram,9 is a clever and humorous textual unit interwoven into a conversational exchange, not necessarily of humorous nature (cf. Norrick 1984, Witticisms are contextbound, but occur spontaneously, usually in nonhumorous conversational environment, in contrast to canned jokes, which constitute integral parts, dissociated from the whole discourse .Witticisms are thus similar to non-humorous sayings or proverbs in the sense that they are communicative entities comprehensible even in isolation, but they are usually produced relevantly to (recurrent) conversational contexts (e.g. a conversation on a given topic, such as politics; or upon Witticisms may assume various communicative forms, such as definitions or comments (Chiaro 1992) and serve communicative purposes besides engendering humour.

Ex.9 Political skill is the ability to foretell what is going to happen tomorrow, next week, next month and next year, and have the ability afterwards to say why it didn't happen.

\subsection{Unintentional humor}

It is also called accidental humor, into physical and linguistic forms. Accidental linguistic humor originates either from errors in logic or mispronunciation or misspelling Accidental physical humor involves minor incidents and pratfalls, for instance, a slipping person on a banana peel or spilling juice on someone's shirt. These types of incidents are considered to be funny only if they occur in surprising and incongruous manner and the person who experiences these events is not seriously hurt or awkwardly embarrassed. The main difference between the intentional and unintentional humor lies in the fact that in the case of intentional humor, the speaker intends to say or do things in order to create hilarious situations. While in the case of unintentional humor, the humorous effect is achieved without the intent or the knowledge of the speaker (Martin, 2007, p.14).

\subsection{Retorts}

Another humorous form is the retort .It overlaps with the category of witticism produced in response to a preceding utterance. A retort can be defined as a quick and witty response to a preceding turn with which it forms an adjacency pair With the exception of routines repeated by given interlocutors, retorts are not expected by the producers of the first pair parts (while non-humorous adjacency pairs, typically, are predictable). A retort is produced with a view to amusing the hearer, in which case it is a manifestation of sarcasm or aggressive humor.

Ex.10 A: Fashion today goes toward tiny...

B: So you've got the most fashionable brain.

One of the most common mechanisms governing retorts is the humorous interlocutor's pretended misunderstanding of the preceding turn, which prompts him her to skew the intended meaning and activate another one(Norrick 1993).

\subsection{Methodology 12.0Modal of analysis}

The study intends to pursue and investigate the whole manifestations of humors types which are studied in during literary curricula of the university at English department. Consequently, the study adopts an eclectic model depending, principally, on Martin (2007) to explore the forms of humor that are can be distinguished by students though. With respect to humor, Martin generally maintains that humor falls in three board categories as jokes, spontaneous conversational humor and unintentional humor spontaneous conversational humor is classified into anecdotes , pun, irony, sarcasm ,satire, teasing ,selfdeprecation , and wit . unintentional or accidental humor which forms the basis of slap-stick a screwball comedy. The procedure

\subsection{The Procedure.}

The conceived strategy is designed in an attempt to provide a clear description of the procedural measure and to obtain an answer to the research question about the ability of the students to identify the humorous texts and the types of the humor. The procedure that is followed in this research covers the population sample, the test and its validity and statistical methods to treat the collected data.

\subsection{Population and Sampling}

According to (Berg,2004:34), the reason behind employing a sample of subject to make generalization about some larger population from a smaller one. The sample of this study is represented by choosing fourth year college students(30 students) at Garmian university, college of languages and human sciences as they are expected to get sort of conscious familiarity with sense of humor at least the most common types of humor that have been studied during literary subjects with all its fields during the fourth years of the college such as drama, novel, poetry and linguistics subjects . The original population of this study consists of EFL 
fourth students of Kurdistan region. The sample has been chosen randomly to represent the population of the study

\subsection{Test Construction}

An educational test is a procedure designed to elicit behavior from which one can make inference about certain characteristics of an individual (Bachman ,1990:20).

In order to achieve the aims of the study, an achievement test that tackles the students' knowledge at the recognition level has been constructed.The test is made up of two tasks two questions both of them at the recognition level. The first task is asking the students to recognize the humorous text and unhumorous texts, the total number of the texts is(10) for question one and (10) texts for question two. In question one (5) texts are humorous texts and other (5) are chosen from different literary subjects without humorous meaning. Those two types of texts are randomly chosen from the most familiar texts in their text books of literature and linguistics during the fourth studying years. See table (1). Each item hold (2) marks for the accurate recognition of the types of the texts ,so question one is out of 20 . At the second task the students are required to identify the types of the humorous that each text has indicated. The students should be able to recognize the type of the humorous text by choosing the appropriate one among the given options that are specified according to the most familiar kinds of humor that the have been studied in literature subjects. The number of the items in task two is (10) and each item hold two marks. The total score is out of (20). The overall performance of the test is out of 40 . See table (1)

Table (1) Clarification of test contents and scores( question 1)

\begin{tabular}{|c|c|c|c|}
\hline 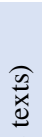 & $\begin{array}{c}\text { Items (types of } \\
\text { the texts) }\end{array}$ & Behaviors & Scores \\
\hline$\underset{⿱ 乛}{ \pm}$ & 1 .humorous & & 2 \\
\hline ఏે & 2 humorous & & 2 \\
\hline$\stackrel{\mathscr{E}}{\cong}$ & 3 humorous & The students should & 2 \\
\hline 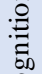 & 4 unhumorous & $\begin{array}{l}\text { be able to recognize } \\
\text { the type of the test }\end{array}$ & 2 \\
\hline 巳 & 5 unhumorous & $\begin{array}{l}\text { whether it is } \\
\text { humorous or }\end{array}$ & 2 \\
\hline Z: & 6 unhumorous & unhumorous . & 2 \\
\hline$\cdot \stackrel{5}{0}$ & 7 humorous & & 2 \\
\hline o & 8 unhumorous & & 2 \\
\hline
\end{tabular}

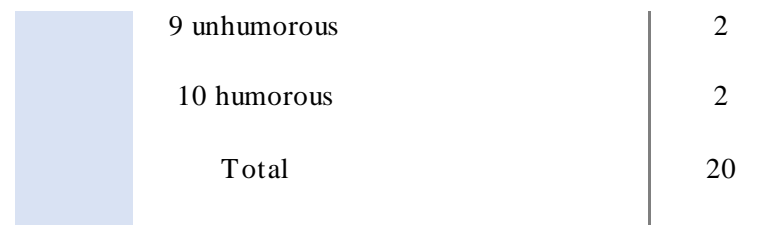

Table (2) Clarification of test contents and scores( question 2)

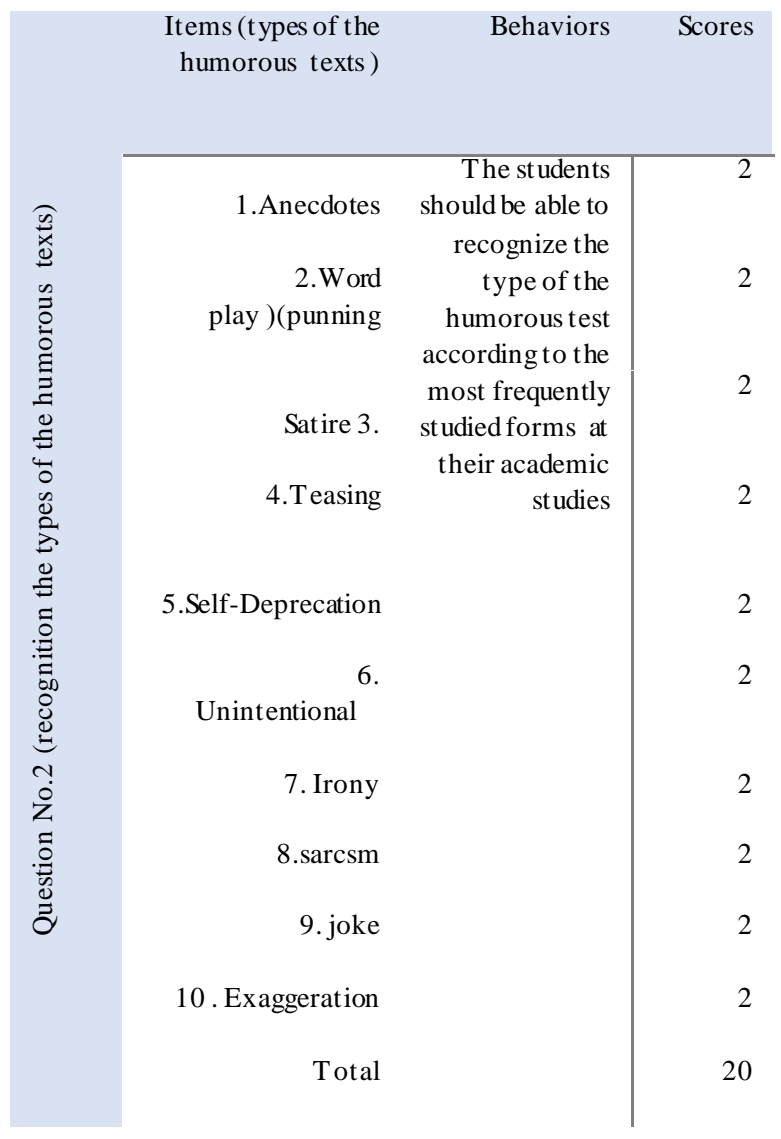

\subsection{Test Validity}

According to Hughes $(2003: 26)$ a test is said to be valid if it measures accurately what it claims to measure. Language tests are created in order to measure such essentially theoretical constructions as :reading ability, fluency in speaking, control of grammar, etc.

Heaton (1990:153)states that every test whether it is a short informal classroom test or a public examination should be valid as the constructor can make it .

Both types of validity ; face validity and content validly have been adopted to the test of the present study. As the test adequately covers the syllabus areas to be test ,that's ensure the content validity.

McNamara (2000:50)adds that the face validity of the test is its surface acceptability to those involved in its development or use but no more.so that the test which doesn't have face validity may not be accepted by the 
candidates, teachers, education authorities or employers. Therefore, the constructed test has been submitted to a jury of specialists and educationalis ts in the field of methodology and applied linguistics to judge its validity and suitability of its items to the sample. The jury members have agreed that the test is suitable after some modifications which are taken into consideration.

The following are the names of the jury members arranged according to their academic status:

1-Prof. Khalil Ismail Rjaya,Ph D,college of Education for human sciences, university of Diyala

2- Prof.Ali Abdullah Mahmood ,Ph D,college of Education for human sciences, university of Diyala.

3-Prof. Sami Abdul Aziz Al-Maamori ,Ph D,college of basic Education, university of Diyala.

4.Asst .prof.Younis Ibraheem Beni-Weiss, PhD.,Garmian university ,college of languages and human sciences .

5-Asst Prof.Ayad Hameed Mahmood ,Ph D,college of Education for human sciences, university of Diyala.

6- Asst Prof.Gazwan Adnan Mohammad ,Ph D,college of Education for human sciences, university of Diyala.

7- Asst Prof. Mohammad Hussein Ahmed ,Ph D,college of Education, university of Garmian .

8-Asst Prof. Zeinab Abbas Jwad $\mathrm{Ph} \mathrm{D,college} \mathrm{of}$ Education for human sciences, university of Diyala.

9- Asst Prof .Inam Yousif Sulaiman. Ph D,college of basic Education, university of Diyala.

10- Instructor .Hemin Adel Mohammad, college of Education, university of Garmian.

\subsection{Pilot Study}

A pilot study is defined as "small preliminary study that makes it possible to check out standardization procedures and general design before investing time and money in the major study " (Eyseneck and Flangan,2000:309).

According to Valette (1967:46) pilot test is help to discover if there are certain points that a sizable number of students have failed to master. Klein( 1974:129) states that Pre-administering the test on a number of subjects is a fundamental step in the procedures followed in the study to ensure validity and reliability of the tool.

The constructed test of the study has been applied to a pilot sample of fifteen students and the data have been manipulated to find the difficulty level DL and the discrimination power DP . the result shows that the test is clear to the students and the required time to answer the items of the test ranges between 30 and 45 minutes .

18.0Item Analysis

According to Score (2005:6) item analysis is the process which examines students' responses to individual test items to assess the quality of those items and of the test as a whole. It's especially valuable in proving which will be used again in later test, but it can also be used to eliminate ambiguous or misleading in a single test administration . the first step papers and arranging them decently, from highest to lowest score. Test papers are separated into two groups, the upper comprising fifty percent of the total group that receive the highest scores and the lowest and the lower comprising equal number of papers of those who receive the lowest scores.

Madsen (1983:181) asserts that the accepted the range of the level of the difficulty is from 0.30 to 0.70 .Bloom et. al (1981:95) believe that a good capability of expanding of result can be established if the average difficulty of the items is around $0.50-0.60$ and items vary in difficulty from 0.20 to 0.80 . Each item in the test should separate the proficient subjects from those who lack the tested skill learned (Harris, 1969:105).

by using SPSS it has been found that the difficulty level of the applied test items for question one and question two ranges between $45 \%$ and $70 \%$.

Satire and sarcasm are considered as the most difficult subjects for the students as their difficulty level less than $45 \%$ and that is acceptable to discriminate between high and low examinees .

The result of items analysis proved that they have acceptable level of difficulty and satisfactory discrimination power. See table (3)

Table( 3) Difficulty level and discrimination power of test items for Question (1)

\begin{tabular}{|c|c|c|c|}
\hline $\begin{array}{l}\text { Number } \\
\text { Of Items }\end{array}$ & $\begin{array}{l}\text { Types Of } \\
\text { The Text }\end{array}$ & $\begin{array}{r}\text { Difficulty } \\
\text { Level }\end{array}$ & $\begin{array}{r}\text { Discrimination } \\
\text { Power }\end{array}$ \\
\hline 1 & humorous & 0.56 & 0.46 \\
\hline 2 & humorous & 0.53 & 0.46 \\
\hline 3 & humorous & 0.35 & 0.33 \\
\hline 4 & $\begin{array}{c}\text { unhumor } \\
\text { ous }\end{array}$ & 0.48 & 0.26 \\
\hline 5 & $\begin{array}{l}\text { unhumor } \\
\text { ous }\end{array}$ & 0.53 & 0.60 \\
\hline 6 & $\begin{array}{c}\text { unhumor } \\
\text { ous }\end{array}$ & 0.56 & 0.20 \\
\hline 7 & humorous & 0.53 & 0.33 \\
\hline 8 & $\begin{array}{c}\text { unhumor } \\
\text { ous }\end{array}$ & 0.33 & 0.46 \\
\hline 9 & $\begin{array}{l}\text { unhumor } \\
\text { ous }\end{array}$ & 0.73 & 0.40 \\
\hline 10 & humorous & 0.67 & 0.46 \\
\hline
\end{tabular}


Table (4) Difficulty level and discrimination power of test items for Question 2

\begin{tabular}{c|lcc}
$\begin{array}{c}\text { Number } \\
\text { Of } \\
\text { Items }\end{array}$ & $\begin{array}{l}\text { Types Of } \\
\text { Humorous }\end{array}$ & $\begin{array}{c}\text { Difficulty } \\
\text { Level }\end{array}$ & $\begin{array}{c}\text { Discrimination } \\
\text { Power }\end{array}$ \\
\hline 1 & Anecdotes & 0.53 & 0.40 \\
2 & Word & 0.57 & 0.46 \\
3 & Satire & 0.33 & 0.26 \\
4 & Teasing & 0.47 & 0.33 \\
5 & Deprecation & 0.63 & 0.47 \\
6 & Unintentional & 0.40 & 0.33 \\
7 & Irony & 0.53 & 0.26 \\
8 & Sarcasm & 0.33 & 0.60 \\
9 & Joke & 0.73 & 0.64 \\
10 & Exaggeration & 0.77 & 0.40 \\
& & &
\end{tabular}

\subsection{Test Reliability}

A reliable test "as one that produces essentially the same results consistently on different occasions when the conditions of the test remain the same. (Madsen, 1983:210).

Anastasia (1976:103) defines reliability the consistency as of scores obtained by the same person when reexamined with the same test on two occasions under the same conditions.

To obtain the reliability of the test in this study, a test -retest method has been used .

A test-retest method is a simple way to obtain a testretest reliability index to find whether the testees are similarly ranked in two successive applications of the test. The test has been given to the students on 29th of October ,2017 . After two weeks the same group of students have tested again. The score of first and the second administration have been compared and Person Correlation coefficient formula has been used to find Correlation coefficient which is ( 0.81$)$ and this is acceptable as reliability index.

\begin{tabular}{|c|c|}
\hline \multicolumn{2}{|c|}{ Reliability Statistics } \\
\hline Cronbach's Alpha & N of Items \\
\hline & \\
\hline 0.816 & 3 \\
\hline
\end{tabular}

\subsection{Final Administration of the Test}

Depending on the outcomes of the pilot administration which apparently manifest that the test is valid, reliable, discriminative and with relatively an acceptable level of difficulty, the test is submitted to final administration of the study on 12th of April. The study sample is of (30) randomly-selected students from the population which is the fourth year college students of university. The instructions are explained to clarify any ambiguity. The test was administered to the sample of the fourth year of the Department of English, college of languages and human sciences under the same controlled conditions.

\subsection{Scoring Scheme}

The applied test has consisted of two tasks, task one deals with recognition of humorous and nonhumouros text, whereas task two deals with recognition part)

The objectivity of the test has made it possible to set an adequate and precise scoring scheme. Twenty marks where assigned to the first task. Each correctly answered item in the first task which contains (10) items, is allotted two marks . Each correctly answered item in task two, which contains also (10) items, is allotted two marks for the recognition of different types of humorous. Unanswered items and items that are answered incorrectly are marked wrong and given zero. See table (5) and (6) which represent the scores of the students at question one and question two.

\subsection{Result Analysis}

In order to achieve the aim of the study and to verify its hypotheses, the collected data has been analyzed statistically by using SPSS .The students responses of the achievement test .This analysis helps to get some insight into the difficulties in the area of recognition of humorous and its types.

\subsection{Students' General Performance}

To know if the students actually face difficulty in identifying the humorous text, students' mean score and standard deviation are found. They are (23.07) and (5.889) respectively. The $\mathrm{T}$ test formula for one sample has been applied, the calculated $\mathrm{T}$-value is (2.852) which is higher than the tabulated one which is at 0.05 level of significance and degree of freedom 99. As shown in table (7) which explains that there are significant differences between students level of performance .This indicates that the students in general face difficulty in recognition of humorous test . That's approved the first hypothesis which shows that there is difficulty in the area of humorous text . 
Table (7)

The mean score and

standard deviation and T-value of students' performance

\begin{tabular}{|c|c|c|c|c|c|c|}
\hline & $\mathrm{N}$ & Mean & $\begin{array}{r}\text { Std. } \\
\text { Devia }\end{array}$ & $\begin{array}{l}\text { Test } \\
\text { Valu }\end{array}$ & $\mathrm{T}$ & $\begin{array}{r}p- \\
\text { value }\end{array}$ \\
\hline Tota & 30 & 23.0 & 5.88 & 20 & 2.852 & 0.008 \\
\hline
\end{tabular}

24.0Students ' Performance at Recognition of the Texts

To approve that the students' performance at recognition of unhumourous texts is better than their recognition of humorous text.Students mean score and standard deviation in recognition of humourous text are obtained. They are (4.13) and (2.345) respectively . while Students mean score and standard deviation in recognition of unhumourous text are obtained.They are (4.67) and (3.497). The mean score of unhumorous text is higher than the mean score of humorous text , this indicates that the humorous text is more difficult for the students to recognize than unhumourous text. See table (8)

Table(8) Comparison of Humorous Text and Unhumorous

\begin{tabular}{c|cc}
$\begin{array}{c}\text { Type Of The } \\
\text { Text }\end{array}$ & Mean & Std. Deviation \\
\hline Humorous & 4.13 & 2.345 \\
Unhumorous & 4.67 & 3.497
\end{tabular}

The T-test formula for one sample has been applied to the computed t-value is ( 7.109) while the tabulated one is (2.389) at 0.05 level of significance with degree of freedom 99 as shown in table (9) below :

Since the computed $t$-value is higher than the tabulated one, this means that there are significant differences between students level of performance. These result show again that the subjects face serious difficulties in recognition of humorous texts.

25.0 Performance according to the types of humorous texts

In order to identify which types of humorous texts is more difficult than another, this section deals with analysis of students responses according to the types of humor in each selected text of question two .The frequency and percentages of the students' performance on each types (10 most familiar types ) are shown in the following table:

Table (8) indicates that the percentages of the correct answers of the students according to the types of humorous texts ranges between $33 \%$ and $73 \%$. It is worth mentioning that the acquisition is attained by scoring 10 out of 20 .

The percentage of students' correct answers range between $(33 \%, 37 \%$ and $40 \%)$ which means that the level of acquisition has not been attained, i.e. the subjects fail to master these types of humor namely sarcasm, satire, teasing and unintentional. This means that the subjects face serious difficulties in recognizing these types of humor. Yet the acquisition of the subjects of sarcasmand satire are the same as they hold the same percentage which is $33 \%$.This is due to the similarities between these two types of humor which make confusion to the students .

Furthermore the recognition of Anecdotes which hold $47 \%$ among the correct responses of the students means that the result are very close to the cutting point, but still the students fail to master this type .

The percentage of correct responses of the students at recognition of irony and word play(punning)which is $50 \%$, this means that the subject reach the cutting point of mastering these two types of humor.

Self -deprecation' level of acquisition is little above the cutting point which hold $57 \%$.

The highest level of acquisition at the recognition of joke and exaggeration which hold $73 \%$ it is clear that the students are able to master these two types .Theses results indicate that these two types are the easiest types.

\section{Comparison between}

Students'recognition of Humor and its Types

In order to investigate the students' ability to recognize the humorous and unhumorous texts in general and the types of humor exactly , a comparison between students' mean scores at the two question is done. It is clear from table(11)that there is significant difference between students' level of performance in question one and question two which is 1.867 and the theoretical level of performance which is 20 in favor of the latter. Table( 12) shows that in question one the mean score of students achievements at the recognition of humorous text in general without mentioning the type of humor is (12.47), whereas the mean score of students achievements at the recognition the type of humor in details is 10.60 which is lower than the former. These results indicate that recognition the specific types of humor is more difficult than the realization of the humor generally.

Table (11) Statistics of students performance at question one and question two

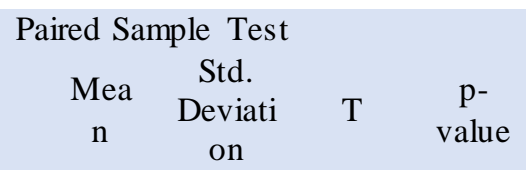




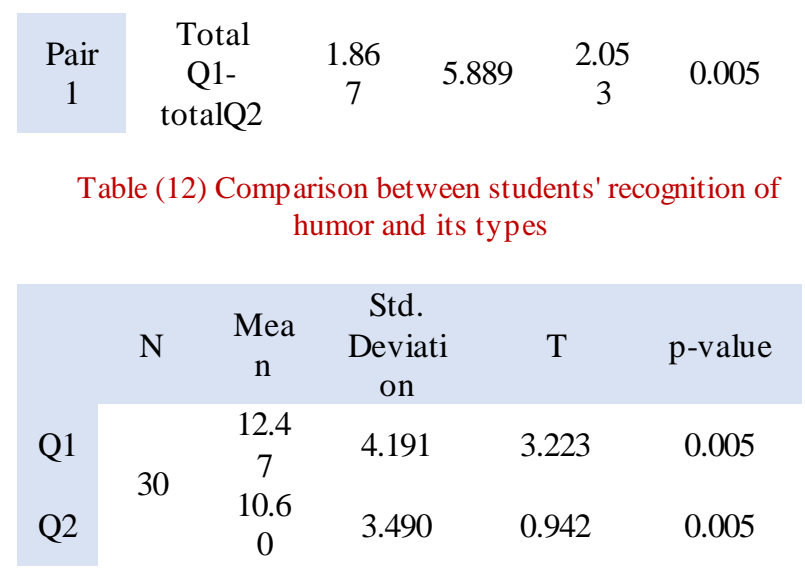

\section{6-Conclusions}

1-Iraqi EFL university students face serious difficulties in mastering humor, especially at the recognition of humorous texts .

2-Students face more difficulties in recognition the types of humor .

3-Moving from the most difficult to the least difficult type, students can be arranged as follows :sarcasm, satire ,unintentional ,teasing, irony, anecdotes , word play, deprecation, joke and exaggeration.

4- The sources of students' errors can be attributed to certain factors among them the little attention, if any paid to humor and its types in the content of the syllabuses taught to the students .

5-The weak performance of the students in recognition the types of humor is the complexity of humor itself and the differences from its counterpart in Arabic and Kurdish as those two language are spoken in Iraqi universities .

6- The most problematic types are sarcasm and satire and the most easiest one is joke.

\section{References}

11 Anastasia,Anne(1976)Psychological Testing . 4th ed.New York :Macmillan publishing Co.,Inc.

12 Alexander, R. D. (1986). Ostracism and indirect reciprocity: The reproductive significance of humor. Ethology and Sociobiology, 7(3), 253270. doi:10.1016/0162-3095(86)90052-X.

13 Arbuckle, G. A. (2008). Laughing With God: Humor, Culture and Transformation. Minnesota: Liturgical.

14 Attardo, S. 1994, Linguistic Theories of Humor [M]. Berlin and NewYork: Moutode Gruyter.
15 Bachman, Lyle F.(1990)Fundamental Consideration in Language Testing.Oxford university press.

16 Berg ,Brauce L.(2004)Qualitative Research Methods for Social Sciences.

17 Boston :person education.

18 Banas, J. A., Dunbar, N., Rodriguez, D., \& Liu, S.-J. (2011). A review of humor in educational settings: Four decades of research. Communication Education, 60(1), 115-144. doi:10.1080/03634523.2010.496867.

19 Bariaud, Francoise. Chapter 1: Age Differences in Children's Humor. Journal of Children in Contemporary Society. 1989, 20(1-2), 15-45. DOI: 10.1300/J274v20n01_03. ISSN 0276-6256. Dostupné také z: http://www.tandfonline.com/doi/abs/10.1300/J274 v20n01_03

20 Critchley, S. (2002). On humour. Thinking in action. London: Routlege.

21 Charles R.Gruner. 2000, The Game of Humor : a comprehensive theory of why we laugh. Transaction Publishers, New Brunswick, New Jersey 0893.

22 Delabastita, D. (1993). There's A Double Tongue. Amsterdam: Rod Opi.

23 Garner, R. L. (2006). Humor in pedagogy: How ha-ha can lead to aha!. College Teaching, 54(1), 177-180. http://dx.doi.org/10.3200/CTCH.54.1.177-180.

24 Gordon, G. (1999). Turning Toward philosophy: Literary Device And Dramatic Structure in Plato's Dialogues. Pennsylvania: The Pennsylvania State University Press.

25 Herawan, T, Deriss, M. M., \& Albawajy, J. (2013). Proceedings of the First International Conference on Advanced Data and Information Engineering. London: Springer.

26 Heaton ,J.B.(1990)Writing English Language Tests :A Practical Guide for Teachers of English as a Second Language or Foreign Language. 3rd ed. London :Longman Group Limited

27 Hobbes, Thomas. (1660/1987). Thomas Hobbes. In John Morreall (Ed.), Philosophy of laughter and humor (pp. 19-20).

28 Holmes, J. 2000. Politeness, power and provocation: How humour functions in the

29 workplace. Discourse Studies, 2(2), 159 - 185.

30 Hughes ,Arthur (2003) Testing for language Teachers . Cambridge :Cambridge University Press.

31 Humor. Dictionary and Thesaurus: MerriamWebster [online]. Merriam-Webster, Incorporated, 
2015 [cit. 2016-03-30]. Dostupné z: http://www.merriamwebster.com/dictionary/humor

32 Humor. Dictionary, Encyclopedia and Thesaurus: The Free Dictionary [online]. Farlex, Inc, (C20032016 [cit. 2016-03-30]. Dostupné z: http://www.thefreedictionary.com/humor.

33 Madsen ,Harold S.(1983) Techniques in Testing.Oxford .Oxford University Press

34 Martin, R. A., 2000. Humor. In: A.E. Kazdin, ed. Encyclopedia of psychology. Washington, DC: American Psychological Association.

35 Martin, R. A., Puhlik-Doris, P., Larsen, G., Gray, J., \& Weir, K. (2003). Individual differences in uses of humor and their relation to psychological well-being: Development of the Humor Styles Questionnaire. Journal of Research in Personality, 37(1), 48-75. doi:10.1016/S0092-6566(02)00534 2.

36 Martin, R. A., 2007. The Psychology of Humor. An integratetive approach .burlington,MA:Eles vier.

37 Marta Dynel( 2009)Beyond a Joke: Types of Conversational Humour Journal Compilation ${ }^{a}$ 2009 Blackwell Publishing Ltd. Language and Linguistics Compass 3/5 (2009): 1284-1299, 10.1111/j.1749-818x.2009.00152.x.

38 McCreaddie, M., \& Wiggins, S. (2008). The purpose and function of humour in health, health care and nursing: a narrative review. Journal of Advanced Nursing, 61(6), 584-595. doi:10.1111/j. 1365-2648.2007.04548.x.

39 McNamara,Tim (2000)Language Testing. Oxford .Oxford University Press

40 Meyer, J. C. (2000). Humor as a double-edged sword: Four functions of humor in communication. Communication Theory, 10(3), 310-331. doi:10.1111/j.14682885.2000.tb00194.x.

41 Morreall, J. (1983). Taking laughter seriously. Albany: State University of New York Press.

42 Morreall, J. (1987). A new theory of laughter. In J. Morreall (Ed.), The philosophy of laughter and humor.

43 Munoz, B. J. (2005). Learning through humor: using humorous resources in the teaching of foreign languages. The A.T.I.S Bulletin. 42-46pp.

44 Norrick, Neal. 1993. Conversational joking: humor in everyday talk. Bloomington: Indiana University Press.

45 Majeed,R.M.(2013) Apragmatic Analysis of Humor in Some Selected English Texts.
Unpublished M.A thesis. University of Sulamani. Faculty of humanities and languages.

46 Score, Pak M(2005) Understanging Items Analysis Reports OEA. University of Washington , Seattle.www.adobe .com products/acrobat read step 2.Htm.Retivied on 9/12/2018

47 ŠEĎOVÁ, Klára. Pedagogické efekty humoru ve výukové komunikaci. Pedagogika, Praha: Pedagogická fakulta Univerzity Karlovy, 2012, roč. 62, č. 4, s. 426-441. ISSN 0031-3815.

48 Urszula Michalik and Iwona Sznicer (2017)The Use of Humor in the Multicultural

49 Working Environment Institute of English, University of Silesia, Ul. Gen. Stefana GrotaRoweckiego 5, 41-205 Sosnowiec, Poland.

50 Wickberg, D., 1998. The senses of humor: Self and laughter in modern America thacaI:Cornell university press

51 Xiaosu. Y . (2009) Conversational Implicature Analys is of Humor in American Situation Comedy "Friends". University Gent

52 ( https://www.write-out-loud.com/types-of-verbalhumor.html ) 
Table(5) Students' performance and scores at question (1)

\begin{tabular}{|c|c|c|c|c|c|}
\hline NO.of students & $\begin{array}{l}\text { Correct responses of } \\
\text { the humorous text } \\
\text { Recognition }\end{array}$ & $\begin{array}{c}\text { Marks out of } \\
\text { (10) } \\
5 \text { items }\end{array}$ & $\begin{array}{c}\text { Correct responses of } \\
\text { the unhumorous text } \\
\text { Recognition }\end{array}$ & $\begin{array}{l}\text { Marks out of } \\
\text { (10) } \\
5 \text { items }\end{array}$ & $\begin{array}{l}\text { Total mark of } \\
\text { question } 1 \text { ( out } \\
\text { of } 20)\end{array}$ \\
\hline 1 & 2 & 4 & 4 & 8 & 12 \\
\hline 2 & 1 & 2 & 3 & 6 & 8 \\
\hline 3 & 3 & 6 & 3 & 6 & 12 \\
\hline 4 & 2 & 4 & 2 & 4 & 8 \\
\hline 5 & 1 & 2 & 4 & 8 & 10 \\
\hline 6 & 4 & 8 & 5 & 10 & 18 \\
\hline 7 & 5 & 10 & 5 & 10 & 20 \\
\hline 8 & 2 & 4 & 4 & 8 & 12 \\
\hline 9 & 2 & 4 & 5 & 10 & 14 \\
\hline 10 & 3 & 6 & 4 & 8 & 14 \\
\hline 11 & 4 & 8 & 4 & 8 & 16 \\
\hline 12 & 3 & 6 & 5 & 10 & 16 \\
\hline 13 & 2 & 4 & 5 & 10 & 14 \\
\hline 14 & 2 & 4 & 4 & 8 & 12 \\
\hline 15 & 2 & 4 & 4 & 8 & 12 \\
\hline 16 & 5 & 10 & 5 & 10 & 20 \\
\hline 17 & 3 & 6 & 5 & 10 & 16 \\
\hline 18 & 3 & 6 & 4 & 8 & 14 \\
\hline 19 & 3 & 6 & 4 & 8 & 14 \\
\hline 20 & 1 & 2 & 4 & 8 & 10 \\
\hline 21 & 3 & 6 & 5 & 10 & 16 \\
\hline 22 & 0 & 0 & 2 & 4 & 4 \\
\hline 23 & 2 & 4 & 1 & 2 & 6 \\
\hline 24 & 4 & 8 & 4 & 8 & 16 \\
\hline
\end{tabular}




\begin{tabular}{|c|c|c|c|c|c|}
\hline 25 & 1 & 2 & 3 & 6 & 8 \\
\hline 26 & 0 & 0 & 2 & 4 & 4 \\
\hline 27 & 3 & 6 & 5 & 10 & 16 \\
\hline 28 & 2 & 4 & 4 & 8 & 12 \\
\hline 29 & 2 & 4 & 4 & 8 & 12 \\
\hline 30 & 2 & 4 & 2 & 4 & 8 \\
\hline Total & 72 & 144 & 115 & 230 & \\
\hline
\end{tabular}

Table (6) Students' performance and scores at question (2)

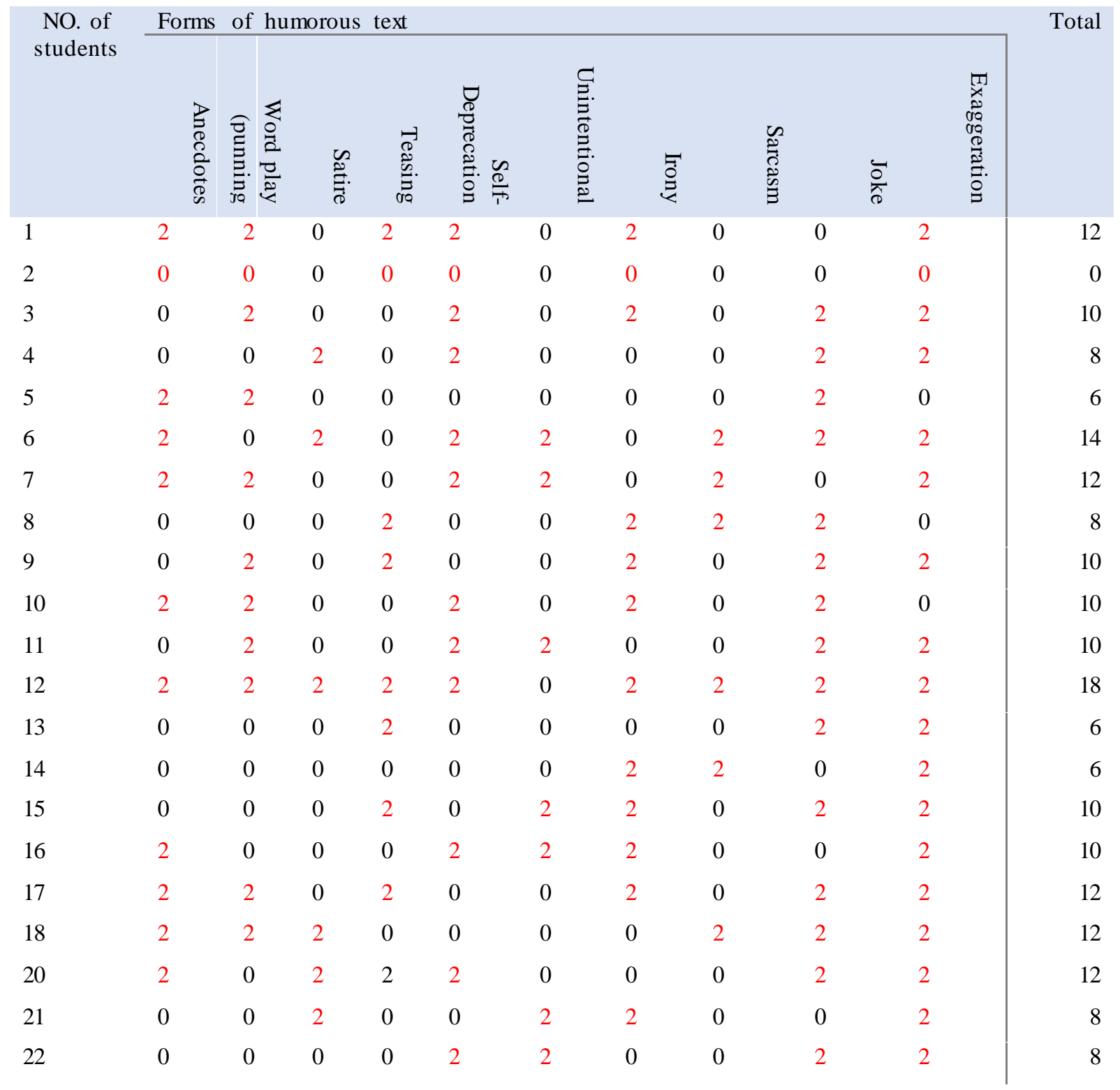




\begin{tabular}{|c|c|c|c|c|c|c|c|c|c|c|c|}
\hline 23 & 0 & 2 & 0 & 0 & 2 & 0 & 0 & 0 & 2 & 0 & 6 \\
\hline 25 & 2 & 2 & 2 & 2 & 2 & 2 & 2 & 2 & 2 & 2 & 20 \\
\hline 24 & 2 & 2 & 0 & 2 & 0 & 0 & 2 & 0 & 2 & 2 & 12 \\
\hline 26 & 0 & 0 & 2 & 0 & 2 & 2 & 2 & 0 & 0 & 0 & 8 \\
\hline 27 & 0 & 0 & 2 & 0 & 0 & 2 & 2 & 2 & 2 & 0 & 10 \\
\hline 28 & 2 & 2 & 0 & 2 & 2 & 0 & 0 & 0 & 2 & 2 & 12 \\
\hline 29 & 2 & 2 & 2 & 2 & 2 & 2 & 0 & 2 & 2 & 2 & 18 \\
\hline 30 & 0 & 2 & 0 & 0 & 2 & 2 & 0 & 0 & 0 & 2 & 8 \\
\hline $\begin{array}{r}\text { Total of } \\
\text { correct } \\
\text { responses }\end{array}$ & 14 & 15 & 10 & 11 & 17 & 12 & 15 & 10 & 21 & 22 & \\
\hline
\end{tabular}

Table (9)

The mean score and standard deviation and T-value of students'
performance at question one
\begin{tabular}{|c|c|c|c|c|c|c|} 
& & Paired Sample Test & Test Value & T-tabulated & T-computed & p-value \\
\hline $\begin{array}{c}\text { Humorous } \\
\text { Unhumourous }\end{array}$ & 2.867 & 2.209 & 20 & 2.389 & 7.109 & 0.001 \\
\end{tabular}


Table (10 ) Frequency and percentage of students 'responses to the types of humor

\begin{tabular}{|c|c|c|c|}
\hline Item order & $\begin{array}{c}\text { Types of humorous } \\
\text { texts }\end{array}$ & Correct responses & Percentage \\
\hline 1 & 1.Anecdotes & 14 & $47 \%$ \\
\hline 2 & 2.Word play )(punning & 15 & $50 \%$ \\
\hline 3 & Satire 3. & 10 & $33 \%$ \\
\hline 4 & 4.Teasing & 11 & $37 \%$ \\
\hline 5 & 5.Self-Deprecation & 17 & $57 \%$ \\
\hline 6 & 6. Unintentional & 12 & $40 \%$ \\
\hline 7 & 7. Irony & 15 & $50 \%$ \\
\hline 8 & $8 . \operatorname{arcsm}$ & 10 & $33 \%$ \\
\hline 9 & 9. joke & 21 & $70 \%$ \\
\hline 10 & 10. Exaggeration & 22 & $73 \%$ \\
\hline
\end{tabular}

